As soon as I came across Prof. Bayliss's statement I wrote to him pointing out what seemed a use of "metabolic" earlier than 1883. Not possessing the work in the original, I asked Prof. Bayliss what was the exact word translated "metabolic," as I wished to know whether it was any derivative of "Stoff wechsel," the present-day German word for "metabolism." Prof. Bayliss replied at once to say that he had found the original passage, which he kindly transcribed for me as follows :- "Zweitens, Erscheinungen, die sich auf chemische Veränderungen, sowohl der Bestandtheile der Zelle selbst, als des umgebenden Cytoblastems, beziehen, diese kann man metabolische Erschein-

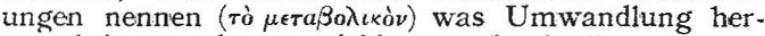
vorzubringen oder zu erleiden geneigt ist."

"Metabolische," and not any derivative of "Stoffwechsel," is, therefore, the word employed. This is not the only passage in which Schwann uses the word; on p. 197 he speaks of "metabolic power," and again later, in contrasting a crystal and an organism, he remarks that the metabolic properties are "quite pecu. liar to cells." The word occurs twice more at the close of this remarkable chapter.

As the origin of anything cannot fail to be interesting, and as the word "metabolism" is so very much used in biological exposition, I have thought it well to ask you to publish these remarks.

D. Fraser Harris.

\section{Cultural Amœbæ from the Intestine of Man.}

I sHoulo like to thank your reviewer for his commendatory remarks in NATURE of December 2I, I9I6, on the account of the parasitic Protozoa which I contributed to the "Animal Parasites of Man." Without in any way wishing to raise a discussion, I think it should be pointed out, in respect to his statement about Amoeba limax, that much information concerning these cultural organisms that may occur in the human intestine will be found under the designation "cultural amcbæ" on pp. 42, 618, 742 and 743 of my work. As your reviewer rightly infers, $A$. limax is not now strictly the name of a single species, but rather of a group or type of free-living forms which show differences among themselves, but can be cultivated on artificial media. It is not easy to point out marked differential characters between them and Entamœebæ, especially after consideration of the work of Drs. Williams and Calkins, to which reference is made by me on p. 42 and pp. 742 and 743 of the book.

Cambridge.

H. B. Fantham.

DR. FANTHaM has given information concerning the culture of "cultural amœebæ," and mentions (p. 6is) that they are non-pathogenic, but beyond the statement (previously overlooked), on pp. 42, 743, that they exhibit morphological variations there is no note of their characters. The account does not therefore afford adequate help to those who, during microscopic examination of a stool, find for the first time amœbæ with a very large karyosome, and desire to know what they are. Although amœbæ of the limax type exhibit variations under different methods of culture, as described by Williams and Calkins, reference might have been made to the striking karyosome by which amœbæ of this type, as found in the human intestine, are often distinguishable. In view of the frequent references in recent literature to "amœbæ of the limax type," some account under this designation might have been given, e.g. on p. 42 , following the account of the morphology of species of Entamœba from the intestine. The Reviewer.

\section{FLOUR STANDARDS.}

REFERENCE was made in Nature of Novem. ber 23 and 30 , I916, to the Order directing that millers shall increase the yield of flour from wheat by about 5 per cent. The result was that the corresponding proportion of "offal" was mixed in with the flour. An Order has now been made to the effect that a further 5 per cent. must be added to the flour. This may be done either by taking another five parts of offal for that purpose, or (and this is a most important new departure), at the miller's option, by adding five parts of flour derived from barley, maize, rice, or oats. In addition, he may add voluntarily another five parts, making ten parts in all over and above the previous increase in flour yield of seventy-one to about seventy-six parts of flour from roo parts of wheat. The result is a com. pulsory ro per cent. or a voluntary I $_{5}$ per cent. more bread with the use of the same quantity of wheat.

In his article in NATURE of November 30 , the present writer deprecated any further addition beyond the first 5 per cent., except in case of dire necessity, because of the deterioration in quality of the resultant flour. The necessity has apparently arisen, but the use of flour from other cereals is a valuable alternative in the present difficulty. Except for the absence of gluten, barley and the other flours indicated will not differ greatly from wheaten flour. They will not of themselves have rising power, and consequently the gluten of the wheaten flour present will have to buoy up the whole loaf during fermentation. But, on the other hand, there will be an absence of the proteolytic and starch-converting enzymes which are so active in the whiter portion of the offal of wheat, and act so adversely on the gluten and starch of the flour.

So early as January, I9I5, the Lancet, in a leading article, suggested the use of cornflour in order to eke out the wheat supply. In consequence some experiments were made by Lieut. $W$. Claude Jago, the results of which were published in the Lancet of February $\mathrm{r}_{3}$ of the same year. Loaves of bread were baked from (I) London household flour only, (2) a mixture of ninety parts of the same flour and ten parts of cornflour, and (3) a mixture of eighty parts of the flour and twenty parts of cornflour. The bread from the mixtures was slightly less in volume, but fairly equal to that from the flour only in texture and appearance. This judgment was confirmed by the editor of the Lancet, who stated that the loaves "appeared to be quite acceptable." Cornflour is, of course, maize starch, and is manufactured very largely in the United States. If this variant of maize flour be permitted, its employment will result in a considerably larger yield of bread and of a type which will accord with the reasonable tastes and requirements of the British public.

William Jagr. 